\title{
Jefferson
}

Thomas Jefferson University

$\overline{\text { HOME OF SIDNEY KIMMEL MEDICAL COLLEGE }}$

\section{Jefferson Journal of Psychiatry}

Volume 8 | Issue 2

Article 2

June 1990

\section{Editor's Column}

Edward Kim, M.D.

Thomas Jefferson University Hospital

Follow this and additional works at: https://jdc.jefferson.edu/jeffjpsychiatry

Part of the Psychiatry Commons

Let us know how access to this document benefits you

\section{Recommended Citation}

Kim, M.D., Edward (1990) "Editor's Column," Jefferson Journal of Psychiatry. Vol. 8 : Iss. 2 , Article 2. DOI: https://doi.org/10.29046/JJP.008.2.009

Available at: https://jdc.jefferson.edu/jeffjpsychiatry/vol8/iss2/2

This Article is brought to you for free and open access by the Jefferson Digital Commons. The Jefferson Digital Commons is a service of Thomas Jefferson University's Center for Teaching and Learning (CTL). The Commons is a showcase for Jefferson books and journals, peer-reviewed scholarly publications, unique historical collections from the University archives, and teaching tools. The Jefferson Digital Commons allows researchers and interested readers anywhere in the world to learn about and keep up to date with Jefferson scholarship. This article has been accepted for inclusion in Jefferson Journal of Psychiatry by an authorized administrator of the Jefferson Digital Commons. For more information, please contact: JeffersonDigitalCommons@jefferson.edu. 


\section{Editor's Column}

This issue of the Jefferson Journal of Psychiatry impressively reflects current trends in the American Psychiatric Association. Past President Herb Pardes took as his theme "The Research Alliance: Road to Clinical Excellence." Current President Elissa Benedek has adopted the theme "Our Children, Our Future" for the 1991 annual meeting. Adjusting to the responsibilities of chief editorship (under the watchful eye of my predecessor, Dr. Trefzger), I am impressed by the evolution of the Journal and the manuscripts submitted for review.

Drs. Desai and Sieg have provided two extensive reviews on neuropsychiatric disorders, reminding us that psychiatrists in this Decade of the Brain must address central nervous system disorders as well as their epiphenomena. To this end, Dr. Burgess has investigated cognitive deficits in borderline patients, bringing us closer to a contemporary understanding of what has traditionally been considered a purely intrapsychic and/or interpersonal disorder.

While the future of psychiatry may rest on research excellence, children represent the future of society and humanity. Drs. Clawson and Koshes describe a model program for serving indigent women and their children who may experience psychological distress. Dr. Mayugba-Sugai discusses the devastating effects of sexual abuse on a young boy. Dr. Hooks explores the potentially traumatic consequences of adoption - for both parent and child. These articles point out the striking lack of resources and attention devoted to delivering adequate and appropriate mental health interventions to children.

The Jefferson Journal of Psychiatry is proud to provide a forum for the thoughts and opinions of residents and fellows who are aware of the important issues facing psychiatry in the 90's and wish to meet these challenges head-on. As incoming chief editor I am honored to be involved in the evolution of the Journal and hope that it continues to address the academic and affective needs of its readership.

Edward Kim, M.D.

Chief Editor

Jefferson Journal of Psychiatry: A Resident Publication 